Jpn. J. Oral Biol., 26: 986-989, 1984.

\title{
Induction of L-type colonies from Streptococcus mutans
}

\author{
Hisae Baba \\ Department of Oral Microbiology (Chief: Prof. Taisuke Akisada), \\ Higashi Nippon Gakuen University, School of Dentistry, \\ Tobetsu, Ishikari-gun, Hokkaido 061-02, Japan
}

[Accepted for publication: June 20, 1984]

Key words: L-type colony / Streptococcus mutans

It is considered that Streptococcus mutans (Str. mutans) plays an important role in the initiation and development of dental caries. But the genetics of this species is yet to be clarified. The reason is that because its cell walls are hard, the genetic transformation does not readily progress. It occurs at an extremely low frequency ${ }^{1,2)}$.

L-forms are cell wall-defective organisms, and differ largely from Mycoplasmas in that they do not require cholesterol for mulitplication and the GC contents of gene DNA are higher ${ }^{3)}$. It has been shown that L-type colonies can not grow in the same medium as the parent strain increases, but a change sets in on the stable L-forms as a subculture using a suitable agar medium advances, and the maintenance of the gene of the parent strain can be held ${ }^{4}$. Several researchers ${ }^{5-12}$ ) have demonstrated that the genetic transformation of cell wall-defective microbial forms, such as L-forms, protoplasts and spheroplasts, are readily caused by cell fusion, transfection and so on.

The purpose of this study is to induce L-type colonies with an aim of obtaining stable L-forms from the strains of cariogenic Str. mutans.

\section{Materials and Methods}

The strains were anaerobically incubated for $8 \mathrm{~h}$ at $37^{\circ} \mathrm{C}$ in Trypticase soy broth (TSB, $\mathrm{BBL}$ ) containing $0.5 \%$ yeast extract (Difco). Then the cells were harvested by centrifugation, washed twice with phosphate buffered saline $\mathrm{pH} 7.0$ and suspended in a deionized water to an optical density at $600_{n m} 2.0$
(Baush \& Lomb, spectronic 88 with 1/2" test tube). An aliquot of this cell suspension was then mixed with an equal volume of $0.05 \mathrm{M}$ Tris-Maleate $\mathrm{NaOH}$ buffer $\mathrm{pH} 6.5$ containing $200 \mu \mathrm{g}$ N-Acetylmuramidase $\mathrm{SG}^{13)}$ (Seikagaku Kogyo Co., Ltd.) per ml, 0.01 M magnesium chloride and $2 \%$ sodium chloride. As a control, a mixture of the buffer containing only salts and the cell suspension was used. After incubation for $60 \mathrm{~min}$ at $37^{\circ} \mathrm{C}, 0.1 \mathrm{ml}$ of the reaction mixture was spread on the agar plates prepared for induction of L-type colonies and incubated anaerobically at $37^{\circ} \mathrm{C}$ for two weeks. During the period, attention was paid to the growth of the colonies presenting a so-called fried egg appearance. Viable cell counts, expressed in the number of colony-forming units (GFU) per $\mathrm{ml}$, in the above control reaction mixture, were determined by the pour-plate technique using TSB agar plate containing $0.5 \%$ yeast extract. The composition of the medium used to induce L-type colonies was as follows: TSB as a basal medium, $0.5 \%$ yeast extract, $1.0 \%$ agar purified (Difco), $5 \%$ horse serum (M.A. Bioproducts, screened for Mycoplasmas) heated for $30 \mathrm{~min}$ at $56^{\circ} \mathrm{C}$, potassium penicillin $\mathrm{G}$ (Meiji Seika Co., Ltd.) to $100 \mu \mathrm{g}$ per $\mathrm{ml}$, and several kinds and concentrations of chemical compounds are listed in Table 1.

The electron microscopic photograph of L-type colony was prepared according to the method described by Siegel, et al. ${ }^{14)}$

\section{Results and Discussion}

Table 2 shows the strains used in this 
Table 1 The kinds and concentrations of chemical compounds added to the medium for induction of L-type colonies of Str. mutans strains

\begin{tabular}{ccccl}
\hline $\begin{array}{c}\text { Chemical } \\
\text { compound }\end{array}$ & $\mathrm{NaCl}$ & $\mathrm{MgCl}_{2}$ & $\mathrm{NH}_{4} \mathrm{Gl}$ & Glycine \\
\hline Concentration & $0(\%)$ & $0(\mathrm{mM})$ & $0(\mathrm{mM})$ & $0(\%)$ \\
& 1 & 10 & 10 & 0.5 \\
& 2 & 20 & 20 & 1.0 \\
& 3 & 50 & 50 & 1.5 \\
& 4 & 100 & 100 & \\
& 5 & & & \\
\hline
\end{tabular}

study, the presence and number of L-type colonies induced, and the kinds and concentrations of the additions in a suitable medium for each strain of cariogenic Str. mutans to induce L-type colonies. From eleven strains including all serotypes of (a) to (g) of Str. mutans, E-49(a), HS-6(a), BHT(b), Fa-1(b), OMZ-70(c), 67-1(c), 6725(c), OMZ-176(d), P-4(e), OMZ-175 (f) and $6715(\mathrm{~g})$, L-type colonies were induced. However, from five strains, GS5(c), Ingbritt(c), LM-7(e), $\mathrm{KIR}(\mathrm{g})$ and $\operatorname{AHT}(\mathrm{g})$, L-type colonies failed to appear. Five- to seven-day incubation was required for the appearance of L-type colonies in these strains. The number of the colonies induced differed among the strains and were divided into three grades of $(+)$ to $(\mathrm{m})$. The kinds and optimal concentrations of the chemical compounds in a suitable medium also differed among the strains. In other words, in a concentration of sodium chloride participating in the osmotic pressure of the cells, an addition of $2 \%$ was suitable for OMZ-70 strain. However, $3 \%$ was suitable for HS-6, BHT, 67-1, 6725 and P-4 strain, 4\% for E-49 and $\mathrm{Fa}-1$, and both 2 and $3 \%$ were adequate for OMZ-175, while both 3 and $4 \%$ were suitable for OMZ-176 and 6715 strain, respectively.

Dienes and Sharp ${ }^{15)}$ described that, in the

Table 2 Induction of L-type colonies from sixteen strains of Str. mutans

\begin{tabular}{|c|c|c|c|c|c|c|}
\hline \multirow{2}{*}{$\begin{array}{l}\text { Str. mutans } \\
\text { strain }\end{array}$} & \multirow{2}{*}{$\begin{array}{l}\text { Sero } \\
\text { type }\end{array}$} & \multirow{2}{*}{$\begin{array}{l}\text { L-type colonies } \\
\text { induced }\end{array}$} & \multicolumn{4}{|c|}{ Optimum conc. of the additions } \\
\hline & & & $\underset{(\%)}{\mathrm{NaCl}}$ & $\underset{(\mathrm{mM})}{\mathrm{MgCl}_{2}}$ & $\underset{(\mathrm{mM})}{\mathrm{NH}_{4} \mathrm{Cl}}$ & $\begin{array}{c}\text { Glycine } \\
(\%)\end{array}$ \\
\hline $\mathrm{E}-49$ & $a$ & $H^{*}$ & 4 & 0 & 0 & 0 \\
\hline HS-6 & & + & 3 & $10-20$ & 0 & 0 \\
\hline BHT & $b$ & W & 3 & $10-20$ & 0 & 0 \\
\hline $\mathrm{Fa}-1$ & & + & 4 & 0 & $10-100$ & 0 \\
\hline OMZ-70 & $c$ & H & 2 & $10-20$ & 0 & $0.5-1.0$ \\
\hline $67-1$ & & + & 3 & $10-20$ & 0 & 0 \\
\hline 6725 & & + & 3 & $10-20$ & 0 & 0 \\
\hline GS-5 & & - & & & & \\
\hline Ingbritt & & - & & & & \\
\hline $\mathrm{OMZ}-176$ & $d$ & W & 3,4 & $10-20$ & 0 & 0 \\
\hline$P-4$ & $e$ & + & 3 & $10-20$ & 0 & 0 \\
\hline LM-7 & & - & & & & \\
\hline OMZ-175 & $f$ & $H$ & 2,3 & $10-20$ & 0 & $1.0-1.5$ \\
\hline 6715 & $g$ & + & 3,4 & $10-20$ & 0 & 0 \\
\hline KIR & & - & & & & \\
\hline AHT & & - & & & & \\
\hline
\end{tabular}

*; - : 0, +: 1-100, H: 101-1000, H: over 1000 of L-type colonies per $10^{8}$ viable cells (CFU) 
induction of L-forms from several species of bacteria, the effect of an addition of inorganic substances, such as magnesium chloride, ammonium chloride and others varied, largely depending on the type of the inorganic substances added. In this study, an addition of magnesium chloride was proved effective at concentrations of 10 to $20 \mathrm{mM}$ on the nine strains except for two strains of E-49 and Fa-1 in which no L-type colony was obtained by the addition. Only on Fa-1 strain, ammonium chloride was successful at concentrations of 10 to $100 \mathrm{mM}$. Michel and Hijmans $^{16)}$ reported that glycine had the effect on the induction of group A streptococcal L-forms. In this paper, in the two strains, i.e. OMZ-70 and OMZ-175, an addition of glycine was effective at concen-

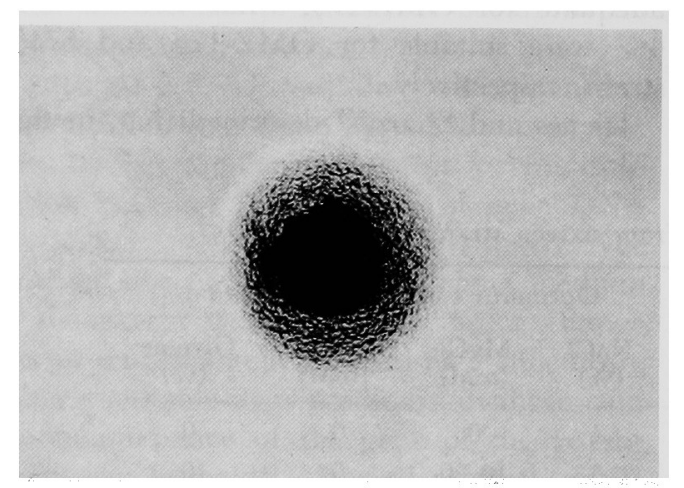

Fig. 1 L-type colony of Str. mutans BHT strain $(\times 40)$. So-called fried egg appearance is seen.

\section{References}

1) Perry, D. and Kuramitsu, H. K.: Genetic Transformation of Streptococcus mutans. Infect. Immun. 32: 1295-1297, 1981.

2) Kuramitsu, H. K. and Long, C. M.: Plasmid-Mediated Transformation of Streptococcus mutans. Infect. Immun. 36: 435-436, 1982.

3) Dienes, L.: Biology and morphology of Lforms with a note on the relation of L-forms to Mycoplasmas. In: The Role of Mycoplasmas and L-forms of Bacteria in Disease. Edited by Sharp, J. T. pp. 285-312, Spring- trations of 0.5 to $1.0 \%$ and 1.0 to $1.5 \%$, respectively.

In the microscopic photograph of a colony (Fig. 1, from Str. mutans BHT strain) obtained by the above-mentioned method, the so-called fried egg appearance was seen, and in the electron microscopic photograph of this colony (Fig. 2), the cell wall-defective forms and various sized cells were observed.

From the above observations and the facts that horse serum screened for Mycoplasmas was used and no L-type colonies appeared when only the medium prepared for induction was incubated, it was concluded that L-type colonies obtained in this study were true cell wall-defective colonies from cariogenic Str. mutans.

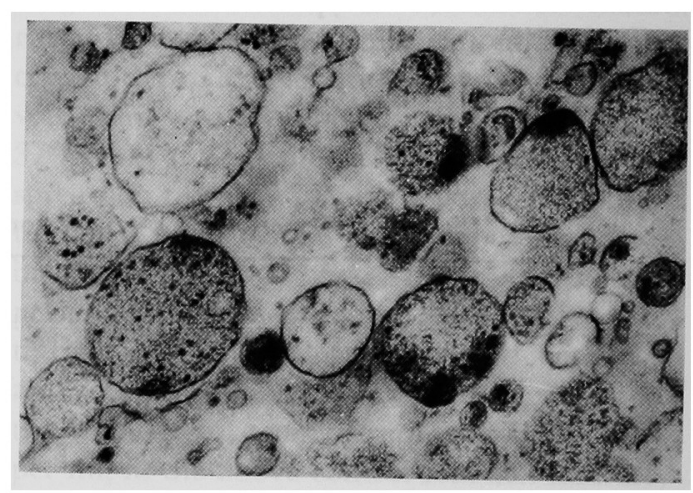

Fig. 2 Electron micrograph of L-type colony of Str. mutans BHT strain $(\times 24,000)$. All of the cells lack a cell wall and are surrounded by unit membrane.

field, Charles C. Thomas Publ. Co., 1970.

4) Okazaki, N., Akema, R. and Miyamoto, Y.: Induction and bacteriological characteristics of group A streptococcal L-forms. Jpn. J. Bacteriol., 36: 695-702, 1981.

5) Ferenczy, L., Kevei, F. and Zsolt, J.: Fusion of fungal protoplasts. Nature 248: 793-794, 1974.

6) Fodor, K. and Alföldi, L.: Fusion of Protoplasts on Bacillus megaterium. Proc. Natl. Acad. Sci. USA 73: 2147-2150, 1976.

7) Hopwood, D. A., Wright, H. M., Bibb, M. J. and Cohen, S. N.: Genetic recombination through protoplast fusion in Streptomyces. Nature 268: 171-174, 1977. 
8) van Solingen, P. and van der Plaat, J. B.: Fusion of Yeast Spheroplasts. J. Bacteriol. 130: 946-947, 1977.

9) Hopwood, D. A. and Wright, H. M.: Bacterial Protoplast Fusion: Recombination in Fused Protoplasts of Streptomyces coelicolor. Molec. gen. Genet. 162: 307-317, 1978.

10) White, T. B., Doyle, R. J. and Streips, U. N.: Transformation of a Bacillus subtilis L-form with bacteriophage DNA. J. Bacteriol. 145: 878-883, 1981.

11) White, T. B. and Streips, U. N.: Parameters of transfection of a L-form from Bacillus subtilis. In: Genetics and Cellular Technology. Edited by Streips, U. N. et al. pp. 153-162, Marcel Dekker Inc., New York, 1982.

12) Hirachi, Y., Kato, Y., Matsumoto, T., Ueyama, Y., Furuyama, S., Kurono, M., Toda, Y. and Kotani, S.: Isolation of recombinants doubly and triply drug resistant to streptomycin, tetracycline and chlorampheni- col by polyethylene glycol induced cell fusion of singly resistant Staphylococcus aureus Lforms. Biken J. 25: 111-120, 1982.

13) Yokogawa, K., Kawata, S. and Yoshimura, Y.: Lytic enzyme from Streptomyces globisporus 1829 strain. Agr. Biol. Chem. 37: 799-808, 1973.

14) Siegel, J. L., Hurst, S. F., Liberman, E. S., Coleman, S. E. and Bleiweis, A. S.: Mutanolycin-Induced Spheroplast of Streptococcus mutans Are True Protoplasts. Infect. Immun. 31: 808-815, 1981.

15) Dienes, L. and Sharp, J. T.: The role of high electrolyte concentration in the production and growth of L-forms of bacteria. J. Bacteriol., 71: 208-213, 1956.

16) Michel, M. F. and Hijmans, W.: The additive effect of glycine and other amino acid on the induction of L-phase of group A beta-hemolytic streptococci by penicillin and D-cycloserine. J. Gen. Microbiol. 23: 35-46, 1960. 